\title{
Correction to: In vitro bulb formation of direct and indirect regeneration of Lilium orientalis Cv. "Starfighter" plants
}

Nora M. Youssef ${ }^{f^{*}}$, Shimaa A. Shaaban², Zenna Fawzia Ghareeb ${ }^{3}$ and Lobna S. Taha ${ }^{1}$

Correction to: Bull Natl Res Cent (2019) 43:211

https://doi.org/10.1186/s42269-019-0246-z

After publication of the original article (Youssef et al., 2019), we were notified that the corresponding author's name has been erroneously spelled. It should be corrected from Yousef to Youssef.

The original article has been corrected.

\section{Author details}

'Ornamental Plants and Woody Trees Department, National Research Centre,

P.O. Box 12622, Dokki, Giza, Egypt. ${ }^{2}$ Department of Agricultural Botany,

Faculty of Agriculture, Cairo University, Giza, Egypt. ${ }^{3}$ Botanical Garden

Research Department, Horticulture Res. Inst., Agricultural Research Center,

Giza, Egypt.

Published online: 20 January 2020

\section{Reference}

Youssef et al (2019) Bull Natl Res Cent 43:211. https://doi.org/10.1186/s42269-019$0246-z$

\footnotetext{
* Correspondence: norayousif20@yahoo.com

The original article can be found online at https://doi.org/10.1186/s42269019-0246-z

'Ornamental Plants and Woody Trees Department, National Research Centre,

P.O. Box 12622, Dokki, Giza, Egypt

Full list of author information is available at the end of the article
} 